\title{
PENURUNAN STATUS HAK KEPEMILIKAN ATAS TANAH DARI HAK MILIK MENJADI HAK GUNA BANGUNAN AKIBAT PENYERTAAN MODAL DI PERSEROAN TERBATAS
}

\author{
Mogi Ksatria Prayogi \\ Magister Kenotariatan, Fakultas Hukum, Universitas Narotama Surabaya \\ Email : mogiksatria2018@gmail.com \\ Rusdianto Sesung \\ Magister Kenotariatan, Fakultas Hukum, Universitas Narotama Surabaya \\ Email : rusdianto@narotama.ac.id
}

\begin{abstract}
Land is commonly used as shared capital in establishing limited company. It is used as shared capital because of economic consideration since it holds high economic value in certain times and the value is hard to decrease. Utilization of land as capital share in limited company also stimulates the occurrence of numerous issues since land contains numerous rights mainly concerning propriety rights of the land. The present study aims to elaborate further about ratio legisof propriety rights handed to limited company in regard to the use of land as capital participation in limited company. The method used in the present study is a normative legal research, namely legal research which is conducted by examining the library materials or secondary law while in finding and collecting the data is done by two approaches, namely the law and conceptual approaches. The present study shows that Ratio Legisof propriety rights handed to limited company is prohibited in order to avoid the breaching of maximum limit of land propriety rights. Propriety rights of land that is used as shared capital shall be declined into building rights title in order to change limited company status become legal subject which holds intermediate rights based on the regulation as propriety rights holder. Administration defect will be occurred when this requirement is not fulfilled in which this condition will stimulate the cancelation status of land propriety rights and it will be changed into land owned by the state.
\end{abstract}

Keywords: Propriety Rights, Limited Company, Shared Capital

\begin{abstract}
Abstrak
Tanah seringkali dipergunakan sebagai modal saham dalam pendirian Perseroan terbatas karena pertimbangan dari nilai ekonomisnya karena tanah mempunyai nilai yang terus meningkat dalam kurun waktu tertentu dan cenderung tidak akan mengalami kemerosotan. Penggunaan tanah sebagai modal dalam Perseroan Terbatas tidak lepas dari masalah dikarenakan adanya berbagai macam hak atas tanah khususnya berkaitan dengan Hak Milik atas tanah. Penulis dalam penelitian ini ingin menelaah dan menganalisa lebih lanjut tentang ratio legis tidak diberikannya hak milik atas tanah bagi Perseroan Terbatas dan akibat hukum status hak milik atas tanah yang dijadikan penyertaan modal dalam Perseroan Terbatas. Metode penelitian yang digunakan adalah penelitian hukum normatif, yaitu penelitian hukum yang dilakukan dengan cara meneliti bahan pustaka atau bahan hukum sekunder sedangkan pendekatan masalah dilakukan dengan menggunakan pendekatan undang-undang dan pendekatan konseptual. Hasil penelitian menunjukkan bahwa Ratio Legis tidak diperbolehkannya Perseroan Terbatas mempunyai tanah dengan hak milik untuk menghindari
\end{abstract}


penyelundupan-penyelundupan terhadap batas maksimum pemilikan tanah. Hak Milik atas tanah yang dialihkan melalui penyertaan kedalam perusahaan harus terlebih dahulu diturunkan haknya menjadi hak guna bangunan agar Perseroan Terbatas sebagai menjadi subyek hukum yang menerima peralihan hak tersebut memenuhi syarat yang telah ditentukan oleh Undang-Undang sebagai pemegang hak atas tanah. Tidak dipenuhinya persyaratan tersebut menyebabkan terjadinya cacat administrasi yang dapat mengakibatkan dibatalkannya hak atas tanah yang bersangkutan dan status tanah menjadi tanah negara.

Kata Kunci : Inbreng, Hak Milik, Perseroan Terbatas

\section{Pendahuluan}

\subsection{Latar Belakang}

Indonesia sebagai negara yang sedang berkembang mempunyai keinginan yang kuat untuk melaksanakan pembangunan terutama di bidang ekonomi dan bisnis. Perkembangan pembangunan di bidang ekonomi dan bisnis di Indonesia dewasa ini dapat dilihat dari semakin banyaknya usahawan yang memilih untuk mendirikan badan usaha yang berbentuk perseroan terbatas dalam melakukan aktivitas usahanya karena bentuk badan usaha ini dirasa mempunyai kelebihan dibanding badan usaha lainnya. ${ }^{1}$

Badan usaha berbentuk Perseroan Terbatas menjadi banyak diminati karena pada umumnya mempunyai kemampuan untuk mengembangkan diri, mampu mengadakan kapitalisasi modal dan sebagai wahana yang potensil untuk memperoleh keuntungan baik bagi instansinya sendiri maupun bagi para pendukungnya (pemegang saham). Oleh karena itu, bentuk Badan Usaha Perseroan Terbatas sangat diminati oleh masyarakat. ${ }^{2}$

Pendapat ini mendasarkan pada kenyataan bahwa Perseroan Terbatas mempunyai kemampuan untuk mengembangkan diri dan berpotensi memberikan keuntungan bagi instansinya sendiri maupun bagi para pemegang saham. Ini bisa kita lihat dalam realita yang ada di tengah-tengah kita, organisasi ekonomi (badan usaha) yang dimiliki oleh konglomerat yang menguasai beberapa sektor perekonomian bentuknya adalah Perseroan Terbatas.

Apabila ditinjau dari kegiatan Perseroan Terbatas berpengaruh luas di bidang perekonomian, sedang dari segi kelembagaan institusi hukum ini disukai oleh masyarakat karena mempunyai beberapa karakteristik yang berbeda dengan institusi bisnis yang lain, karakteristik tersebut adalah sebagai berikut $:^{3}$

1. Pertanggungjawaban yang timbul sematamata dibebankan kepada harta kekayaan yang terhimpun dalam asosiasi;

2. Sifat mobilitas atas hak penyertaan; dan

3. Prinsip pengurusan melalui suatu organ.

Pada pendirian perseroan, perbuatan hukum pendirian oleh 2 (dua) atau lebih pendiri tidak melahirkan perjanjian antara para pendiri, melainkan mengakibatkan adanya perjanjian antara semua pendiri disatu pihak dan perseroan di pihak lain. Berdasarkan perjanjian pendirian dimaksud para pendiri berhak menerima saham dalam

\footnotetext{
Agus Budiarto, Kedudukan Hukum Dan Tanggung Jawab Pendiri Perseroan Terbatas, Jakarta: Ghalia Indah, 2002, hlm. 1

Sri Rejeki Hartono, Kapita Selekta Hukum Perusahaan, Bandung: Mandar Maju, 2002, hlm. 1-2

Rudhi Prasetya, Kedudukan Mandiri Perseroan Terbatas, Bandung: Citra Aditya Bakti, 1996, hlm. 12
} 
perseroan dan sekaligus mereka wajib melakukan penyetoran penuh atas saham yang diambilnya. ${ }^{4}$

Berkaitan dengan penyetoran modal dalam Perseroan Terbatas, Pasal 34 ayat (1) UndangUndang No. 47 Tahun 2007 Tentang Perseroan Terbatas (UUPT) menyatakan : "Penyetoran atas modal saham dapat dilakukan dalam bentuk uang dan/atau dalam bentuk lainnya". Adanya ketentuan tersebut menjadikan bentuk modal dasar dalam Perseroan Terbatas menjadi fleksibel dalam artian modal tidak harus selalu berbentuk uang. Penyetoran dalam bentuk lain tersebut adalah baik berupa benda berwujud maupun benda tidak berwujud dan dapat dinilai dengan uang.

Lahirnya aturan tersebut direspon oleh masyarakat yang akan mendirikan Perseroan Terbatas dengan menjadikan tanah sebagai modal dasar dalam pendirian Perseroan Terbatas. Tanah seringkali dipergunakan sebagai modal saham dalam pendirian Perseroan terbatas karena pertimbangan dari nilai ekonomisnya karena tanah mempunyai nilai yang terus meningkat dalam kurun waktu tertentu dan cenderung tidak akan mengalami kemerosotan. Perbuatan hukum berupa penyetoran tanah sebagai modal dalam pendirian Perseroan terbatas tersebut dinamakan inbreng. Dalam hal inbreng, penilaian setoran modal saham ditentukan berdasarkan nilai wajar yang ditetapkan sesuai dengan harga pasar atau oleh ahli yang tidak terafiliasi dengan Perseroan.

Penggunaan tanah sebagai modal dalam Perseroan Terbatas tidak lepas dari masalah dikarenakan adanya berbagai macam hak atas tanah. Pada umumnya tanah yang dimiliki oleh perseorangan adalah dengan status hak milik. Ketentuan pada Pasal 21 ayat (1) dan (2) UndangUndang Nomor 5 Tahun 1960 Tentang Peraturan Dasar Pokok-Pokok Agraria (UUPA) menyatakan bahwa hak milik hanya dapat dimiliki oleh Warga Negara Indonesia perseorangan dan badan-badan hukum yang ditetapkan oleh Pemerintah dapat memiliki hak milik atas tanah. Badan hukum tersebut menurut Pasal 1 Peraturan Pemerintah No. 38 Tahun 1963 (PP 38/1963) tentang Penunjukkan Badan-Badan Hukum Yang Dapat Mempunyai Hak Milik Atas Tanah Negara dan Hak Pengelolaan, antara lain :

1. Bank-bank yang didirikan oleh Negara.

2. Perkumpulan-perkumpulan yang didirikan oleh Koperasi Pertanian yang didirikan berdasarkan atas Undang-Undang Nomor 79 Tahun 1958 Nomor 139.

3. Badan-badan keagamaan yang ditunjuk oleh Menteri Pertanian / Agraria setelah mendengar Menteri Agama.

4. Badan-badan sosial yang ditunjuk oleh Menteri Pertanian setelah mendengar Menteri Kesejahteraan Sosial.

Dari 4 (empat) jenis badan hukum yang telah disebutkan di atas tidak ada nama Perseroan Terbatas sebagai badan hukum yang dapat mempunyai hak milik. Hal tersebut menimbulkan permasalahan bagi Perseroan Terbatas apabila tanah yang disertakan ke dalam modal Perseroan Terbatas adalah berstatus tanah hak milik. Tanah yang telah disertakan ke dalam modal Perseroan Terbatas menjadi aset dari Perseroan Terbatas itu sendiri karena telah terpisah dari kekayaan pemilik.

\footnotetext{
4 Fred B.G. Tumbuan, "Tugas dan wewenang Organ Perseroan Terbatas Menurut Undang-undang Tentang Perseroan Terbatas", Makalah, disampaikan pada "Sosialisasi Undang-undang tentang Perseroan Terbatas" yang diselenggarankan oleh Ikatan Notaris Indonesia (INI), Jakarta, 22 Agustus 2007, hlm. 3
} 
Dalam posisi ini terjadi suatu kekaburan norma karena meskipun berdasarkan Pasal 21 ayat (1) dan (2) UUPA Perseroan Terbatas tidak menjadi subyek hukum yang dapat mempunyai hak milik, namun di dalam Pasal 27 UUPA juga tidak disebutkan bahwa apabila subyek hukum tidak memiliki kewenangan untuk mempunyai hak milik maka hak milik atas tanah tersebut menjadi hapus.

\subsection{Rumusan Masalah}

1) Apa ratio legis tidak diberikannya hak milik atas tanah bagi Perseroan Terbatas?

2) Apa akibat hukum status hak milik atas tanah yang dijadikan penyertaan modal dalam Perseroan Terbatas?

\subsection{Metode Penelitian}

Penelitian ini menggunakan metode penelitian hukum normatif yang dilakukan untuk mencari pemecahan masalah atas permasalahan hukum yang ada. Pendekatan penelitian yang digunakan adalah pendekatan undang-undang (statute approach) dan pendekatan konseptual (conceptual approach).

\section{Pembahasan}

\subsection{Ratio Legis Tidak Diberikannya Hak Milik}

\section{Atas Tanah Bagi Perseroan Terbatas}

Fakta tentang adanya hubungan antara manusia dengan tanah dapat dipandang sebagai fakta hukum, yaitu fakta atau kenyataan yang diatur dan diberi akibat oleh hukum sehingga dapat juga disebut dengan Rechtsfeiten. Rechtsfeiten diartikan sebagai peristiwa-peristiwa hukum, yaitu peristiwa yang terjadi di dalam masyarakat yang diatur dan diberi akibat oleh hukum. Hubungan antara manusia dengan tanah, tidak terkecuali di Indonesia, selalu diatur oleh hukum. Hukum yang mengatur hubungan antara manusia dengan tanah di Indonesia sebelum kemerdekaan, pada satu pihak diatur oleh hukum adat dan pada pihak lain diatur pula oleh hukum tanah kolonial Belanda yang berpangkal pada Agrarische Wet Staatsblad 1870 No. $55 .{ }^{5}$

\section{Semenjak kemerdekaan Republik} Indonesia, hubungan antara manusia dengan tanah di Indonesia, prinsip dasarnya ditetapkan oleh Pasal 33 ayat (3) Undang-undang Dasar 1945 "Bumi, air dan kekayaan alam yang terkandung di dalamnya dikuasai oleh negara dan dipergunakan untuk sebesar-besarnya kemakmuran rakyat".

Dalam hal penguasaan negara atas tanah mengandung pengertian negara memegang kekuasaan untuk menguasai dan mengusahakan segenap sumber daya agraria yang terdapat dalam wilayah hukum negara Indonesia. ${ }^{6}$

Adanya berbagai macam hak atas tanah dalam Pasal 4 ayat (1) dan ayat (2), Pasal 16 ayat (1) dan Pasal 53 UUPA. Dalam Pasal 4 ayat (1) UUPA menjelaskan bahwa atas dasar menguasai dari Negara maka ditentukan adanya berbagai Hak Atas Tanah. Pasal 4 ayat (1) UUPA menyebutkan : "Atas dasar hak menguasai dari Negara sebagaimana dimaksud dalam Pasal 2, ditentukan adanya macam-macam hak atas permukaan bumi yang disebut tanah, yang dapat diberikan kepada dan dipunyai oleh orang-orang, baik sendiri maupun

Ramli Zein, Hak Pengelolaan Dalam Sistem UUPA, Jakarta: Rineka Cipta, 1995, hlm. 8-9.

6 Umar Said Sugiharto, Suratman dan Noorhudha Muchsin, Hukum Pengadaan Tanah: Pengadaan Hak Atas Tanah Untuk Kepentingan Umum Pra dan Pasca Reformasi, Malang: Setara Press, 2015, hlm. 2 
bersama-sama dengan orang-orang lain serta badan hukum."

Salah satu hak atas tanah sebagaimana disebutkan dalam Pasal 16 ayat (1) UUPA adalah Hak Milik. Menurut Lili Rasjidi, Hak milik adalah hubungan seseorang dengan suatu benda yang membentuk hak pemilikan terhadap benda tersebut. ${ }^{7}$ Dalam hukum tanah yang berlaku di Indonesia, pengertian Hak Milik ditegaskan dalam Pasal 20 ayat (1) UUPA yaitu, "Hak milik adalah hak turun temurun, terkuat dan terpenuh yang dapat dipunyai orang atas tanah dengan mengingat ketentuan dalam Pasal 6."

Turun temurun artinya hak milik atas tanah dapat berlangsung terus selama pemiliknya masih hidup dan bila pemiliknya meninggal dunia maka hak miliknya dapat dilanjutkan oleh ahli warisnya sepanjang memenuhi syarat sebagai subyek hak milik. Sedangkan terkuat artinya hak milik atas tanah lebih kuat dibandingkan hak atas tanah yanglain, tidak mempunyai batas waktu tertentu, mudah dipertahankan dari gangguan pihak lain, dan tidak mudah hapus. Terpenuh artinya hak milik atas tanah memberi wewenang kepada pemiliknya paling luas bila dibandingkan dengan hak atas tanah yang lain, dapat menjadi induk bagi hak atas tanah yang lain, tidak berinduk pada hak atas tanah yang lain, dan penggunaan tanahnya lebih luas bila dibandingkan dengan hak atas tanah yang lain. ${ }^{8}$

Menurut Kartini Muljadi dan Gunawan Widjaja, Hak Milik merupakan hak yang paling kuat atas tanah, yang memberikan kembali suatu hak lain di atas bidang tanah Hak Milik yang dimilikinya tersebut (dapat berupa Hak Guna Bangunan atau Hak Pakai dengan pengecualian Hak Guna Usaha) yang hampir sama dengan kewenangan Negara (sebagai penguasa) untuk memberikan hak atas tanah kepada warganya. ${ }^{9}$ Hak ini, meskipun tidak mutlak sama, tetapi dapat dikatakan mirip dengan eigendom atas tanah menurut Burgerlijk Wetboek yang memberikan kewenangan paling luas pada pemiliknya, dengan ketentuan harus memperhatikan ketentuan Pasal 6 UUPA yang menyatakan bahwa, "Semua hak atas tanah mempunyai fungsi sosial." 10

Menurut Samun Ismaya, ciri-ciri hak milik adalah daapat dijadikan jaminan hutang dengan dibebani hipotek atau credietverband, boleh digadaikan, bisa dialihkan kepada pihak lain, dapat dilepaskan secara sukarela serta dapat diwakafkan. ${ }^{11}$ Sedangkan menurut Boedi Harsono, Hak milik pada dasarnya diperuntukkan khusus bagi warga negara Indonesia saja yang berkewarganegaraan tunggal. Baik untuk tanah yang diusahakan, maupun untuk keperluan membangun sesuatu di atasnya. ${ }^{12}$

Menurut Mohammad Machfudh Zarqoni13, mengenai sifat yang melekat pada hak milik : "Sesuai dengan nama dan sifat hak milik, maka UUPA menetapkan bahwa hak milik tidak terbatas jangka waktu berlakunya. Hak milik juga dapat beralih karena pewarisan dan juga dapat dipindah-

\footnotetext{
Lili Rasjidi, Filsafat Hukum, Apakah Hukum Itu?, Bandung: Remadja Karya, 1988, hlm. 85

Boedi Harsono, Hukum Agraria Indonesia Sejarah Pembentukan Undang-Undang pokok Agraria Isi Dan Pelaksanaannya, Jakarta: Djambatan, 2008.

9 Kartini Muljadi dan Gunawan Widjaja, Hak-Hak Atas Tanah, Jakarta: Kencana Prenada Group, 2003, hlm. 30.

$10 \quad$ Ibid, hlm. 31.

11 Samun Ismaya, Pengantar Hukum Agraria, Surabaya: Graha IImu, 2011, hlm. 62

12 Boedi Harsono, Loc Cit.

13 Mohammad Machfudh Zarqoni, Hak Atas Tanah: Perolehan, Asal dan Turunannya, Serta Kaitannya Dengan Jaminan Kepastian Hukum (Legal Guarantee) Maupun Perlindungan Hak Kepemilikannya (Property Right), Jakarta: Prestasi Pustaka Publisher, 2015, hlm. 37.
} 
kan kepada pihak lain yang memenuhi syarat. Selain itu untuk memenuhi kebutuhan prekreditan modern atas tanah, maka hak milik dapat dijadikan jaminan hutang dengan dibebebani Hak Tanggungan."

Mengenai peralihan hak milik atas tanah diatur dalam Pasal 20 ayat (2) UUPA, yaitu hak milik dapat beralih dan dialihkan kepada pihak lain. Berpindahnya hak milik atas tanah harus didaftarkan ke Kantor Pertanahan Kabupaten / Kota setempat sedangkan berpindahnya hak milik atas tanah karena dialihkan / pemindahan hak harus dibuktikan dengan akta otentik yang dibuat di hadapan Pejabat Pembuat Akta Tanah (PPAT) atau dengan Risalah Lelang apabila perolehannya melalui proses lelang.

Subjek Hak Milik yang dapat mempunyai tanah Hak Milik menurut UUPA adalah perseorangan maupun badan hukum. Perorangan yang dapat mempunyai tanah Hak Milik hanya Warga Negara Indonesia sebagaimana ketentuan Pasal 21 ayat (1) UUPA. Hal ini berarti bahwa perseorangan yang bukan Warga Negara Indonesia tidak dapat mempunyai Hak Milik atas tanah.

Selain perorangan, badan hukum juga dapat mempunyai hak milik atas tanah sebagaimana ketentuan Pasal 21 ayat (2) UUPA yang berbunyi, "Oleh pemerintah ditetapkan badanbadan hukum yang dapat mempunyai Hak Milik dan syarat-syaratnya." Dengan demikian tidak ada pihak lain yang dapat mempunyai Hak Milik atas tanah. Ini berarti setiap orang atau badan hukum yang mempunyai Hak Milik atas tanah tidak begitu saja dapat melakukan pengalihan Hak Milik atas tanah yang dikuasainya tersebut.

Hak Milik atas tanah hanya dapat dialihkan kepada Warga Negara Indonesia (WNI) atau kepada badan hukum sebagaimana yang ditentukan oleh PP 38/1963. Peralihan Hak Milik atas tanah, baik secara langsung maupun tidak langsung kepada orang asing, kepada seseorang yang mempunyai dwi kewarganegaraan atau kepada badan hukum yang tidak ditunjuk oleh pemerintah adalah batal karena hukum dan tanahnya jatuh kepada Negara, artinya tanahnya kembali menjadi tanah yang langsung dikuasai Negara.

Mengenai Badan Hukum Tertentu pada Pasal 21 ayat (2) UUPA menyatakan oleh pemerintah ditetapkan badan-badan hukum yang dapat mempunyai hak milik dengan syarat-syarat. Pemilikan tanah hak milik oleh badan keagamaan dan badan sosial diatur dalam Pasal 49 ayat (1) UUPA yang menyatakan bahwa hak milik tanah badan-badan keagamaan dan sosial sepanjang dipergunakan untuk usaha dalam bidang keagamaan dan sosial diakui dan dilindungi. Badanbadan tersebut dijamin pula akan memperoleh tanah yang cukup untuk bangunan dan usahanya dalam bidang keagamaan dan sosial. ${ }^{14}$

Dari ketentuan tersebut diatas Pemerintah kemudian mengeluarkan PP 38/1963 yang memuat badan-badan hukum apa saja yang dapat mempunyai hak milik :

1. Bank-bank yang didirikan oleh Pemerintah;

14 Erna Sri Wibawanti dan R. Murjiyanto, Hak Atas Tanah Dan Peralihannya, Yogyakarta, Liberty, 2013, hlm. 47 
2. Perkumpulan-perkumpulan

$$
\text { koperasi }
$$
pertanian yang didirikan berdasarkan UU No.79 Th 1958;

3. Badan badan keagamaan yang ditunjuk menteri agama;

4. Badan-badan sosial yang ditunjuk menteri dalam negeri setelah mendengar menteri sosial

Sedangkan menurut Pasal 8 ayat (1) Peraturan Menteri Negara Agraria/Kepala Badan Pertanahan Nasional No.9 Th 1999 Tentang Tata Cara Pemberian dan Pembatalan Hak Atas Tantang Negara dan Hak Pengelolaan, disebutkan bahwa badan-badan hukum yang dapat mempunyai tanah hak milik adalah Bank Pemerintah, Badan Keagamaan dan Badan Sosial yang ditunjuk oleh pemerintah.

Dalam penjelasan Umum PP No.38/1963 Pasal 1 angka (b) menyatakan bahwa Badan-badan keagamaan dan Sosial perlu ditunjuk satu demi satu karena di dalam praktek ternyata sering kali timbul keragu-raguan, apakah suatu badan keagamaan/badan sosial atau bukan. Bahwa badan-badan keagamaan dan sosial dapat ditunjuk sebagai badan-badan yang dapat mempunyai hak milik dapat disimpulkan pada penjelasan Pasal 49 ayat 1 UUPA, sungguhpun hak atas tanah yang tepat bagi badan-badan itu adalah hak pakai sebagai yang ditentukan pula pada Pasal 49 ayat 2. Pemilikan tanah oleh badan-badan inipun terbatas pada tanah-tanah yang digunakan untuk keperluankeperluan yang langsung berhubungan dengan usaha keagamaan dan Sosial. Mengenai tanahtanah yang dipergunakan untuk keperluan lain, badan-badan itu dianggap sebagai badan hukum biasa, artinya tanah-tanah itu tidak dapat dipunyai dengan hak milik, tetapi dengan hak guna bangunan, hak guna usaha atau hak pakai.

Menurut Erna Sri Wibawanti dan R. Murjiyanto, alasan untuk tidak diperbolehkannya badan hukum mempunyai tanah dengan hak milik adalah agar dihindari penyelundupanpenyelundupan terhadap batas maksimum pemilikan tanah yang ditentukan dalam Pasal 17 UUPA. ${ }^{15}$

Dalam Bagian Penjelasan UUPA pada Penjelasan Umum II angka 5 telah ditegaskan pula bahwa pada dasarnya badan-badan hukum tidak dapat mempunyai hak milik. Adapun pertimbangan untuk (pada dasarnya) melarang badan-badan hukum mempunyai hak milik atas tanah, ialah karena badan-badan hukum tidak perlu mempunyai hak milik tetapi cukup hak-hak lainnya, asal saja ada jaminan-jaminan yang cukup bagi keperluankeperluannya yang khusus. Dengan demikian maka dapat dicegah usaha-usaha yang bermaksud menghindari ketentuan-ketentuan mengenai batas maksimum luas tanah yang dipunyai dengan hak milik. Meskipun pada dasarnya badan-badan hukum tidak dapat mempunyai hak milik atas tanah, tetapi mengingat akan keperluan masyarakat yang sangat erat hubungannya dengan faham keagamaan, sosial dan hubungan perekonomian, maka diadakanlah suatu "escape-clause" yang memungkinkan badan-badan hukum tertentu mempunyai hak milik. Dengan adanya "escapeclause" ini maka cukuplah nanti bila ada keperluan akan hak milik bagi sesuatu atau macam badan 
hukum diberikan dispensasi oleh Pemerintah, dengan jalan menunjuk badan hukum tersebut sebagai badan-badan hukum yang dapat mempunyai hak milik atas tanah sebagaimana disebutkan dalam Pasal 21 ayat (2) UUPA. Badanbadan hukum yang bergerak dalam lapangan sosial dan keagamaan ditunjuk dalam Pasal 49 sebagai badan-badan yang dapat mempunyai hak milik atas tanah, tetapi sepanjang tanahnya diperlukan untuk usahanya dalam bidang sosial dan keagamaan itu. Dalam hal-hal yang tidak langsung berhubungan dengan bidang itu mereka dianggap sebagai badan hukum biasa.

Menurut Holder dan Binder, melalui teori harta karena jabatan atau teori von het ambetelijk vermogen, bahwa badan hukum adalah suatu badan yang mempunyai harta yang berdiri sendiri, yang dimiliki oleh badan hukum itu tetapi oleh pengurusnya dan karena jabatannya ia diserahi tugas untuk mengurus harta tersebut. ${ }^{16}$ Perseroan Terbatas adalah badan hukum yang merupakan persekutuan modal. Selain sebagai badan hukum Perseroan, juga merupakan tempat para pihak melakukan kerja sama, yaitu melakukan hubungan kontraktual. Kerja sama ini menciptakan badan hukum yang sengaja diciptakan, yaitu Perseroan sebagai suatu "artifical person". ${ }^{17}$

Sebagai badan usaha yang berbadan hukum, Perseroan Terbatas menyandang hak dan kewajibannya tersendiri, terlepas dari hak dan kewajiban para pemegang saham, anggota Direksi dan Komisaris Perseroan Tersebut. Dalam Pasal 1 angka 1 UUPT disebutkan : "Perseroan Terbatas, yang selanjutnya disebut Perseroan, adalah badan hukum yang merupakan persekutuan modal, didirikan berdasarkan perjanjian, melakukan kegiatan usaha dengan modal dasar yang seluruhnya terbagi dalam saham dan memenuhi persyaratan yang ditetapkan dalam Undang-undang ini serta peraturan pelaksanaannya."

Sebagaimana telah disebutkan diatas bahwa Perseroan Terbatas merupakan badan hukum yang merupakan kumpulan atau persekutuan modal, atau dengan kata lain terdapat beberapa subyek hukum yang menyekutukan modalnya. Secara umum Perseroan Terbatas dalam kedudukannya sebagai subyek hukum akan memiliki kemampuan keuangan yang lebih apabila dibandingkan dengan manusia sebagai subyek hukum. Kemampuan keuangan tersebut akan membawa dampak bahwa Perseroan Terbatas akan mempunyai daya beli yang lebih. Hal inilah yang melatarbelakangi adanya ketentuan bahwa Perseroan Terbatas sebagai badan hukum tidak diperbolehkan mempunya tanah dengan status hak milik.

Hak milik sebagai hak atas tanah yang memiliki sifat turun temurun, terkuat dan terpenuh akan menjadi hak atas tanah yang paling diinginkan oleh subyek hukum. Pasal 7 UUPA telah menyatakan bahwa untuk tidak merugikan kepentingan umum maka pemilikan dan penguasaan tanah yang melampaui batas tidak diperkenankan. Penguasaan tanah yang melampaui batas tersebut dapat terjadi dengan mudah apabila Perseroan Terbatas yang memiliki daya beli lebih diperbolehkan untuk memiliki tanah dengan status hak milik.

\footnotetext{
16 Holder dan Binter dalam Marhaenis Abdul Hay, Hukum Perdata. Jakarta: Badan Penerbit Yayasan Pembinaan Unit Penerbitan Keluarga UPN Veteran, 1986, hlm. 12

17 Jamin Ginting, Hukum Perseroan Terbatas, Bandung: Citra Aditya Bakti, 2007, hlm. 13
} 
2.2. Akibat Hukum Status Hak Milik Atas Tanah Yang Dijadikan Penyertaan Modal Dalam

\section{Perseroan Terbatas}

Pada pendiriannya, Perseroan haruslah mempunyai harta kekayaan tersendiri yang terpisah dari harta kekayaan para pendiri Perseroan dan yang didapat dari pemasukan modal para pendirinya (pemegang saham). Harta kekayaan ini sengaja diadakan dan memang diperlukan sebagai alat untuk mengejar tujuan Perseroan. Adapun pendirian Perseroan Terbatas tidak dapat dilakukan tanpa pemenuhan syarat modal minimun. Pemenuhan syarat modal minimun bertujuan agar pada waktu Perseroan Terbatas didirikan setidaktidaknya sudah mempunyai modal, yaitu sebesar modal dasar (authorized capital), modal ditempatkan (issued capital) dan modal disetor (paid-up capital) yang akan menjadi jaminan bagi pihak ketiga terhadap Perseroan Terbatas. ${ }^{18}$

Secara umum, penyetoran setiap bagian dari modal saham yang diambil bagiannya dilakukan dengan uang tunai, tetapi dalam Pasal 34 ayat (1) UUPT terdapat ketentuan bahwa penyetoran atas modal saham dapat dilakukan dalam bentuk uang dan/atau dalam bentuk lainnya. Menurut penjelasan pasal ini, pada umumnya penyetoran modal adalah dalam bentuk uang. Namun, tidak ditutup kemungkinan penyetoran modal dalam bentuk lain, baik berupa benda atau barang, yang dapat dinilai dengan uang dan yang secara nyata diterima oleh Perseroan. Penyetoran modal dalam bentuk lain selain uang harus disertai rincian yang menerangkan nilai atau harga, jenis atau macam, status, tempat kedudukan, dan lain-lain yang dianggap perlu demi kejelasan mengenai penyetoran tersebut. Hal ini dilakukan semata-mata dengan tujuan untuk memberikan modal (harta kekayaan) pada Perseroan dan memisahkannya dari harta kekayaan pribadi masing-masing para pendiri Perseroan. Bentuk penyetoran modal bentuk lain, biasa disebut "pemasukan barang" atau "pemasukan modal" atau "inbreng". ${ }^{19}$

Pemberian saham sebesar imbalan pemasukan (inbreng) berupa tanah dan/atau bangunan harus ada penilaian terhadap tanah dan/atau bangunan itu terlebih dahulu untuk dikaitkan dengan nilai nominal saham. Dalam hal penyetoran modal saham dilakukan dalam bentuk lain, penilaian setoran modal saham ditentukan berdasarkan nilai wajar yang ditetapkan sesuai dengan harga pasar berdasar penilaian oleh ahli penilai (appraisal) yang tidak terafiliasi dengan Perseroan. Nilai wajar setoran modal saham ditentukan sesuai dengan nilai pasar (market value) atas barang modal yang dimasukkan sebagai setoran saham. Jika nilai pasar tidak tersedia, nilai wajar ditentukan berdasarkan teknik penilaian yang paling sesuai dengan karakteristik setoran, berdasarkan informasi yang relevan dan terbaik. ${ }^{20}$

Pemasukan Tanah kedalam perusahaan akan membuat hak kepemilikan atas tanah akan mengalami peralihan. Mengenai bentuk peralihan hak milik atas tanah dapat dijelaskan sebagai berikut :

1) Beralih, yaitu berpindahnya hak milik atas tanah dari pemiliknya kepada pihak lain dikarenakan suatu peristiwa hukum. Dengan

\footnotetext{
18 Rudhi Prasetya, Op. Cit.., hlm. 185.

19 Tri Budiyono, Hukum Perusahaan : Telaah Yuridis Terhadap Undang-Undang Nomor 40 Tahun 2007 Tentang Perseroan Terbatas, Salatiga: Griya Media, 2011, hlm. 79-80.

20 M. Yahya Harahap, Hukum Perseroan Terbatas, Jakarta: Sinar Grafika, 2011, hlm. 186-187.
} 
meninggalnya pemilik tanah, maka hak miliknya secara hukum berpindah kepada ahli warisnya sepanjang ahli warisnya memenuhi syarat sebagai subyek hak milik.

2) Dialihkan / Pemindahan Hak, yaitu berpindahnya hak milik atas tanah dari pemiliknya kepada pihak lain dikarenakan adanya suatu perbuatan hukum. Contohnya perbuatan hukum yaitu jual beli, tukarmenukar, hibah, penyertaan dalam modal perusahaan (inbreng), lelang. ${ }^{21}$

Mengenai peralihan sebagaimana tersebut diatas haruslah dilihat terlebih dahulu subyek hukum dan obyek perbuatan hukumnya. Mengenai peralihan hak melalui pemindahan hak baik melalui jual beli, tukar-menukar, hibah, penyertaan dalam modal perusahaan (inbreng), lelang ataupun perbuatan hukum yang lainnya yang bersifat mengalihkan hak akan terikat kepada hukum perjanjian dan akan berpedoman kepada syarat sahnya perjanjian yang disebutkan dalam Pasal $1320 \mathrm{BW}$.

Subyek hukum dalam pengalihan hak milik atas tanah harus memenuhi persyaratan yang telah ditentukan dalam UUPA. Apabila hal tersebut tidak terpenuhi maka Hak Atas Tanah yang bersangkutan dapat dibatalkan. Pada Pasal 104 Peraturan Menteri Negara Agraria/Kepala Badan Pertanahan Nasional Nomor 9 Tahun 1999 Tentang Tata Cara Pemberian Dan Pembatalan Hak Atas Tanah Negara Dan Hak Pengelolaan (PMNA/KBPN 9/1999) disebutkan :

1) Pembatalan hak atas tanah meliputi pembatalan keputusan pemberian hak, sertipikat hak atas tanah keputusan pemberian hak dalam rangka pengaturan penguasaan tanah.

2) Pembatalan hak atas tanah sebagaimana dimaksud pada ayat (1) diterbitkan karena terdapat cacat hukum administrasi dalam penerbitan keputusan pemberian dan/atau sertipikat hak atas tanahnya atau melaksanakan putusan pengadilan yang telah memperoleh kekuatan hukum tetap.

Mengenai cacat administrasi yang dimaksud disebutkan dalam Pasal 107 PMNA/KBPN 9/1999 meliputi : a) Kesalahan prosedur; b) Kesalahan penerapan peraturan perundang-undangan; c) Kesalahan subjek hak; d) Kesalahan objek hak; e) Kesalahan jenis hak; f) Kesalahan perhitungan luas; g) Terdapat tumpang tindis hak atas tanah; h) Data yuridis atau data fisik tidak benar; atau i) Kesalahan lainnya yang bersifat hukun administratif.

Terjadinya pembatalan hak atas tanah sebagaimana disebutkan diatas akan membawa konsekuensi hak atas tanahnya hapus dan menjadi tanah negara. ${ }^{22}$ Dalam kaitannya dengan penyertaan tanah sebagai modal dalam perusahaaan agar tanah yang dimasukkan ke dalam perusahaan tidak hapus haknya dan menjadi tanah negara karena subyek hukum tidak memenuhi syarat sebagai pemegang hak milik atas tanah maka dapat terlebih dahulu dilakukan perubahan hak milik atas tanah menjadi hak guna bangunan.

Hak atas tanah dapat ditingkatkan dan diturunkan sesuai dengan kepentingan dari pemegang hak atas tanah tersebut. Penurunan hak

21 Urip Santoso, Pendaftaran dan Peralihan Hak Atas Tanah, Jakatra: Kencana Prenada Group, 2010, hlm. 94

22 Hatta Isnaini Wahyu Utomo, "Hukum Tanah Nasional : Bahan Diskusi Dalam Persiapan Menghadapi Ujian Pejabat Pembuat Akta Tanah 2017", Makalah, disampaikan pada acara Persiapan Menghadapi Ujian PPAT 2017, Universitas Narotama Surabaya, Oktober 2017. 
atas tanah dilakukan untuk memenuhi kebutuhan pemegang hak atas tanah yang kemungkinan tidak memenuhi syarat untuk memegang hak atas tanah dari tanah yang baru saja diterima.

Menurut Keputusan Menteri Negara Agraria/Kepala Badan Pertanahan Nasional Nomor 6 Tahun 1998 tentang Pemberian Hak Milik atas Tanah untuk Rumah Tinggal (Kepmeneg Agraria No.6/1998), terdapat 2 (dua) cara untuk meningkatkan hak atas tanah menjadi Hak Milik:

1. Hak Guna Bangunan atau Hak Pakai atas tanah untuk rumah tinggal kepunyaan perseorangan Warga Negara Indonesia (WNI) yang luasnya $600 \mathrm{~m} 2$ atau kurang, atas permohonan yang bersangkutan dihapus dan diberikan kembali kepada bekas pemegang haknya dengan Hak Milik.

2. Tanah Hak Guna Bangunan atau Hak Pakai atas tanah untuk rumah tinggal kepunyaan perseorangan WNI yang luasnya $600 \mathrm{~m} 2$ atau kurang yang sudah habis jangka waktunya dan masih dipunyai oleh bekas pemegang hak tersebut, atas permohonan yang bersangkutan diberikan Hak Milik kepada bekas pemegang hak.

Untuk pemberian Hak Milik tersebut, penerima hak harus membayar uang pemasukan kepada Negara sesuai ketentuan yang berlaku. Permohonan pendaftaran Hak Milik diajukan kepada Kepala Kantor Pertanahan Kabupaten/Kotamadya setempat.

Sedangkan berdasarkan Keputusan Menteri Negara Agraria/Kepala Badan Pertanahan Nasional Nomor 16 Tahun 1997 tentang Perubahan
Hak Milik menjadi Hak Guna Bangunan atau Hak Pakai dan Hak Guna Bangunan menjadi Hak Pakai (Kepmeneg Agraria No.16/1997), terdapat 2 (dua) macam hak atas tanah yang dapat diturunkan, yaitu:

1. Hak Milik dapat diturunkan menjadi Hak Guna Bangunan atau Hak Pakai dengan jangka waktu 30 (tiga puluh) tahun dan 25 (dua puluh lima) tahun.

2. Hak Guna Bangunan atas Tanah Negara atau atas tanah Hak Pengelolaan kepunyaan perseorangan $\mathrm{WNI}$ atau badan hukum Indonesia diturunkan menjadi Hak Pakai atas permohonan pemegang hak atau kuasanya dengan jangka waktunya 25 (dua puluh lima) tahun.

Permohonan untuk mengubah Hak Milik menjadi Hak Guna Bangunan atau Hak Pakai dan Hak Guna Bangunan menjadi Hak Pakai diajukan kepada Kepala Kantor Pertanahan setempat dengan disertai:

1. Sertifikat Hak Milik atau Hak Guna Bangunan yang dimohon perubahan haknya, atau bukti pemilikan tanah yang bersangkutan dalam hal Hak Milik yang belum terdaftar.

2. Kutipan Risalah Lelang yang dikeluarkan oleh pejabat lelang apabila hak yang bersangkutan dimenangkan oleh badan hukum dalam suatu pelelangan umum.

3. Surat persetujuan dari pemegang Hak Tanggungan, apabila hak atas tanah tersebut dibebani Hak Tanggungan.

4. Bukti identitas pemohon.

Dalam hal Hak Milik yang dimohon perubahan haknya belum terdaftar, maka 
permohonan pendaftaran perubahan hak dilakukan bersamaan dengan permohonan pendaftaran Hak Milik tersebut dan penyelesaian pendaftaran perubahan haknya dilaksanakan sesudah Hak Milik itu didaftar sesuai ketentuan yang berlaku. Dan dalam hal Hak Milik yang dimohon perubahan haknya dimenangkan oleh badan hukum melalui pelelangan umum, maka permohonan pendaftaran perubahan Hak Milik tersebut diajukan oleh badan hukum yang bersangkutan bersamaan dengan permohonan pendaftaran peralihan haknya dan kedua permohonan tersebut diselesaikan sekaligus dengan mendaftar perubahan hak tersebut terlebih dahulu, dan kemudian mendaftar peralihan haknya, dengan tetap memperhatikan ketentuan mengenai Hak Milik yang belum terdaftar yang telah dibahas sebelumnya.

\section{Penutup}

\subsection{Kesimpulan}

Ratio Legis tidak diperbolehkannya Perseroan Terbatas mempunyai tanah dengan hak milik adalah karena Perseroan Terbatas dalam kedudukannya sebagai subyek hukum akan memiliki kemampuan keuangan yang lebih apabila dibandingkan dengan manusia sebagai subyek hukum. Kemampuan keuangan tersebut akan membawa dampak bahwa Perseroan Terbatas akan mempunyai daya beli yang lebih yang dikhawatirkan akan menimbulkan monopoli dalam kepemilkan hak atas tanah. Selain itu yang menjadi alasan larangan bagi Perseroan Terbatas memiliki hak milik atas tanah adalah untuk menghindari penyelundupan-penyelundupan terhadap batas maksimum pemilikan tanah dan memberikan kesempatan yang sama bagi seluruh masyarakat Indonesia untuk dapat memilik hak atas tanah.

Hak Milik atas tanah yang dialihkan melalui penyertaan kedalam perusahaan harus terlebih dahulu diturunkan haknya menjadi hak guna bangunan agar Perseroan Terbatas sebagai menjadi subyek hukum yang menerima peralihan hak tersebut memenuhi syarat yang telah ditentukan oleh Undang-Undang sebagai pemegang hak atas tanah. Tidak dipenuhinya persyaratan tersebut menyebabkan terjadinya cacat administrasi yang dapat mengakibatkan dibatalkannya hak atas tanah yang bersangkutan dan status tanah menjadi tanah negara.

\subsection{Saran}

Diperlukan adanya penjabaran dalam bagian penjelasan UUPA yang menyatakan alasan adanya larangan kepemilikan hak milik atas tanah bagi badan hukum yang menjalankan kegiatan usaha seperti Perseroan Terbatas dan juga perlu dinyatakan secara eksplisit dalam peraturan setingkat Undang-Undang atau Peraturan Pemerintah mengenai ketentuan peralihan hak atas tanah melalui pemasukan ke dalam perusahaan agar mampu memberikan kepastian hukum bagi masyarakat khususnya yang melakukan perbuatan hukum penyertaan modal kedalam perusahaan. 


\section{DAFTAR PUSTAKA}

Agus Budiarto, Kedudukan Hukum Dan Tanggung Jawab Pendiri Perseroan Terbatas, Jakarta: Ghalia Indah, 2002.

Boedi Harsono, Hukum Agraria Indonesia Sejarah Pembentukan Undang-Undang pokok Agraria Isi Dan Pelaksanaannya, Jakarta: Djambatan, 2008.

Erna Sri Wibawanti dan R. Murjiyanto, Hak Atas Tanah Dan Peralihannya, Yogyakarta: Liberty, 2013.

Hatta Isnaini Wahyu Utomo, "Hukum Tanah Nasional : Bahan Diskusi Dalam Persiapan Menghadapi Ujian Pejabat Pembuat Akta Tanah 2017", Makalah, disampaikan pada acara Persiapan Menghadapi Ujian PPAT 2017, Universitas Narotama Surabaya, Oktober 2017.

Jamin Ginting, Hukum Perseroan Terbatas, Bandung: Citra Aditya Bakti, 2007.

Kartini Muljadi dan Gunawan Widjaja, Hak-Hak Atas Tanah, Jakarta: Kencana Prenada Group, 2003.

Lili Rasjidi, Filsafat Hukum, Apakah Hukum Itu?, Bandung: Remadja Karya, 1988.

M. Yahya Harahap, Hukum Perseroan Terbatas, Jakarat: Sinar Grafika, 2011.

Marhaenis Abdul Hay, Hukum Perdata. Jakarta: Badan Penerbit Yayasan Pembinaan Unit Penerbitan Keluarga UPN Veteran, 1986.
Mohammad Machfudh Zarqoni, Hak Atas Tanah: Perolehan, Asal dan Turunannya, Serta Kaitannya Dengan Jaminan Kepastian Hukum (Legal Guarantee) Maupun Perlindungan Hak Kepemilikannya (Property Right), Jakarta: Prestasi Pustaka Publisher, 2015.

Ramli Zein, Hak Pengelolaan Dalam Sistem UUPA, Jakarta: Rineka Cipta, 1995.

Rudhi Prasetya, Kedudukan Mandiri Perseroan Terbatas, Bandung: Citra Aditya Bakti, 1996.

Samun Ismaya, Pengantar Hukum Agraria, Surabaya: Graha IImu, 2011.

Sri Rejeki Hartono, Kapita Selekta Hukum Perusahaan, Bandung: Mandar Maju, 2002.

Tri Budiyono, Hukum Perusahaan : Telaah Yuridis Terhadap Undang-Undang No. 40 Tahun 2007 Tentang Perseroan Terbatas, Salatiga: Griya Media, 2011.

Umar Said Sugiharto, Suratman dan Noorhudha Muchsin, Hukum Pengadaan Tanah: Pengadaan Hak Atas Tanah Untuk Kepentingan Umum Pra dan Pasca Reformasi, Malang: Setara Press, 2015.

Urip Santoso, Pendaftaran dan Peralihan Hak Atas Tanah, Jakarta: Kencana Prenada Group, 2010. 